\title{
INDONESIAN GLOBAL IKHWAN'S RECEPTION AND EXPRESSION TOWARD SUNNAH POLYGAMY IN ONLINE MEDIA
}

\author{
Rizqa Ahmadi, "Wildani Hefni, "* and Mutrofin * \\ * Institut Agama Islam Negeri Tulungagung, Indonesia \\ ** Institut Agama Islam Negeri Jember, Indonesia \\ E-mail: rizqa.uns@gmail.com
}

\begin{abstract}
Evidence of the strength of Indonesian Muslim relations with the text tradition can be found in various practices of daily life. The text referred to in this paper is religious texts, especially hadith. Each group in the community has an expression of diverse receptions to a text. Global Ikhwan, one of the urban Muslim communities in Indonesia which declares the call for polygamy, reveals interesting receptions and expressions to be explored. With a virtual ethnographic approach (netnography), the authors find that they perceive hadith exegesis. The group interpreted the command of polygamy with a more realistic interpretation. They perceive the command of polygamy in the hadith with the meaning of sunnah matrûkah (abandoned sunnah), which is not done by many Muslims. Their expressions are manifested in organizing a short course, coaching for prospective wives who are ready for polygamy, publications, and declarations to various media. If viewed from the aspect of the reception function of the text, the traditions that are receptions are categorized into informative functions, which function as sources of information for carrying out an action.
\end{abstract}

Bukti kuatnya relasi Muslim Indonesia dengan tradisi teks dapat dijumpai dalam berbagai praktik kehidupan sehari-hari. Teks yang dimaksud dalam 
tulisan ini adalah teks keagamaan, khususnya hadis. Setiap kelompok dalam masyarakat memilki ekspresi atas resepsi yang beragam terhadap suatu teks. Global Ikhwan, salah satu kelompok Muslim urban di Indonesia yang mendeklarasikan seruan poligami, telah menampakkan resepsi dan ekspresi yang menarik untuk ditelaah. Dengan pendekatan etnografi virtual (netnografi), penulis menemukan bahwa mereka meresepsi hadis secara eksegesis. Kelompok tersebut memaknai perintah berpoligami dengan penafsiran yang lebih realis. Mereka meresepsi perintah poligami dalam hadis dengan arti sunah matrûkah (sunah yang ditinggalkan), yang tidak banyak dilakukan umat Muslim. Ekspresi mereka terwujud dalam menyelenggarakan daurah (shortcourse), pembinaan terhadap calon istri yang siap dipoligami, publikasi dan deklarasi ke berbagai media. Jika dilihat dari aspek fungsi penerimaan atas teks, hadis-hadis yang diresepsi dikategorikan ke dalam fungsi informatif, yakni berfungsi sebagai sumber informasi untuk melakukan suatu tindakan.

Keywords: Global Ikhwan, sunnah matrûkah, polygamy club

Received: October 29, 2018; Accepted: May 27, 2019

\section{Introduction}

There are several terms to recognize this era, namely the era of social media, the era of post-truth, industrial revolution era 4.0, the era of disruption, or society 5.0. The author interpreted this era with key perceptions, namely an era where various uncertainties arose. Technology is a crucial factor in influencing various changes in life sectors. The existence of this era has affected changes that are very dynamic in various ways. In the economic sector, for example, the era of disruption has made conventional companies out of business, while the creative industry has found momentum. This industrial revolution also requires all lines to take part in creating innovation in everything. If not, it is not easy to compete with others. Moreover, the phenomenon of artificial intelligence is reaching into various lines of life.

The signs to recognize this era are the role of new media that mediates between various activities, both social, economic, political, and others. This media has different characteristics. Staying in an ecosystem that is virtual, online, and supported by a set of electronic devices. The most 
symptomatic are various variants of social media that have become an important part of people's daily lives.

The existence of social media has changed the lifestyle of many people. The characteristics of social media, namely digital interactive, which can communicate in two directions without having to face to face. It has indirectly eroded religious values and the sacredness of social life. In addition, social media is also hypertextual, that is connected between one text to another without limit; it makes the communication process sometimes unconsciously viral (spread) everywhere and causing unexpected excesses. It is also with its virtual characteristics as if the activities carried out by someone are real, but the essence is virtual. Among the other characteristics are networked, simulated (artificial) which both move so fast, and not easy to control.

The disruption era also has an impact on the social sphere of humanities, including the religious expression of urban society. Urban society here is characterized as a technology-literate society, sensitive to change, and innovative. In the context of today's phenomenon, urban society does not have to stay in urban areas geographically, but it is meant as a lifestyle-oriented society as middle-class people. Urban Muslims are also identified with people who like to adopt the popular culture.

The religious expression of urban Muslims attracts the attention of many people. The causes factors are the motivations and religious models that they do. In many phenomena, urban Muslims unknowingly make religion as a commodity (Saputro 2015, 181). True, more women today wear the hijâb, Muslims are competing to go to Umrah, visit halal tourism, seek prophetic treatment and so on, but not least ignore the depth aspects of religiosity. The sacredness of religion, which contains esoteric elements, is replaced by the frenetic expression of Islamic packaged pop culture.

In addition to this phenomenon, there are some people also received a response from the audience, those are the emergence of a declaration of Klub Istri Taat Suami (the Wife Obey Husband Club/KITS) by a group of women at an exhibition event in Bandung, West Java. Based on recognition from Gina Puspita, this club stands as a manifestation of the anxiety of modern society with the proliferation of immoral acts and promiscuity. Polygamy is considered the most powerful step in maintaining the relations of men and women. Polygamy for them is a real solution to the rampant culture of adultery, the practice of prostitution, and the act of abortion (Arasy 2011). 
If it is traced backward or looks at a broader spectrum, behind the declaration, an affiliated group with the Global Ikhwan was first established in Malaysia. The Global Ikhwan itself is a da'wah organization that has economic and political power in Malaysia. The branches of the Global Ikhwan have spread to various countries, even now based in Mecca and Medina.

The club declared by Gina Puspita received a diverse response. Not a little people assume that what they do is something strange and unnatural for most women. The rejection was also done by feminist groups. For feminist activists, their actions have undermined women's dignity and preserved the patriarchal system in modern society. It is an expression of Elin Rozana, as a female activist for the Women's Institute coordinator. Elin said that this refusal is based on complaints received by the agency stating that the practice of polygamy considered to cause psychological distress, physical abuse, and sorrowing of both wife and child (Nisa' 2009, 4).

Although the refusal and opposition from the public, it seems that the Ikhwan's Global Polygamy Club group and its derivatives, such as the Indonesian Polygamy Dauroh, FKPS (Forum Keluarga Poligami Sakinah/Forum for the Polygamy Sakinah Family), KITS (Klub Istri Taat Suami/Husband Obedient Wife Club), and Indonesian Polygamy Forum, these continue to conduct recitations with various movements. They construct normative legitimacy on the movement. Quranic and hadith principles become the foundation for the activities they carry out. For example, the statement of the Quran and the hadith to encourage marriage and also instructions for wives to obey their husbands fully, are often found in the preaching themes of the movement. Interestingly, what is done by these groups often different from most other Muslims. The hadith as the text was accepted by the Ikhwan's Global Polygamy Club and expressed in its way.

Moreover, in the borderless era, namely the industrial revolution era 4.0 and technological disruption era, they are hard working in innovating and using new media as a media of preaching and promotion. Based on some considerations, this study reviews more specifically, the acceptance and expression of the Indonesian Ikhwan Global towards the Sunnah of polygamy. The choice of this theme is because of polygamy as one of the characteristics of the preaching of the group. 
The study about polygamy has been carried out by researchers in an inter-disciplines and with various approaches, both normative, linguistic, feminism, socio-anthropology, history, law, or other approaches. For example, Shahrûr, as in Elkarimah's research, assumed that polygamy was a solution to social problems, not a place to fulfill biological needs. Therefore, the conditions of requirements for the perpetrators of polygamy are different. In Shahrur's interpretation, polygamy is a way of protection for widows who have orphans. It means that women who can be polygamous are widows who have orphans so that the polygamy cannot be done by a male to every female. In addition, the conditions of justice for them are not only fair to wives but also orphans owned by wives. Shahrûr opened the spirit of the command of polygamy through a linguistic approach. Assumptions are constructed on several main points. In Arabic, there is no synonymity (murâdif). This theory implies that the linguistic approach opens up opportunities to dismantle etymological and morphological aspects to enable redefinition of the text. Shahrûr also rejected the existence of atomization (ta'diyah) over the verse of the Quran. In interpreting the verses of the Quran, he uses the intra-textuality method. He sees each verse as a single unit in a larger unit in the Quran. Shahrûr also uses syntagmatic-pragmatic analysis to pursue the meaning contained in the editorial of a text (Shahrûr 1992; Elkarimah 2018, 164).

Siti Musdah Mulia has another perspective in her book, Islam Menggugat Poligami (Islam Sues Polygamy), seeing the practice of polygamy as a practice of dehumanization. Mulia sees with a gender perspective that polygamy is closely related to patriarchal culture. Men are assumed superiority over women to be so visible so that women are placed as secondclass humans, who only play a role in domestic areas (family affairs) only. Whereas, men and women are equal in front of God. Both have the same humanitarian duties and rights. According to her, this is due to the textual understanding of the commands of polygamy in the Quran. It needs contextual interpretation of the verses of polygamy so that the main goal (maqâsid) is revealed that polygamy shari'a does not deviate. Siti Musdah Mulia disagrees in the practice of polygamy was also caused by the excesses raised. According to her, polygamy harms women. Women will experience sociological and psychological disorders when has the wife status of a polygamous husband (Mulia 2004).

Darmawijaya in the legal aspect used the polygamy sharia as positive laws in three countries, Turkey, Tunisia, and Indonesia as the research 
material objects. The approach used is the approach to Islamic law, especially maslahat mursalah. In his conclusion, he has a point of view that the using of criminal threats for polygamy perpetrators had not been applied in many Muslim countries, but its existence began to be considered (Darmawijaya 2015). The study describes the phenomenon of the application of positive laws on polygamy practice. Damawijaya's work emphasizes the extent of the positive implications of the prohibition on the practice of polygamy so that it can produce benefits, not only for women but also for men.

The study about polygamy has also been conducted by Rinawati with a sociology approach. Rinawati examines more specifically, the practice of polygamy from the sociological aspects of communication. Through the dramaturgy theory, she saw the impression that a husband wanted to show for his wives. From the perspective, it can be seen that a husband usually shows an ideal impression on his wives through communication styles, both verbal and nonverbal messages. For example, through verbal messages, the husband uses the same call to all his wives. This practice is conducted among his wives to eliminate the impression of injustice (exaggerating one from the other). He does in the form of non-verbal messages that usually in the form of body movements, touch, communication distance, and so on. It is evidenced by the acknowledgment from the husband (as a research informant) that he honestly gave a different assessment to his wives, but he intentionally did not appear to his wives. It is called in the theory of dramaturgy as impression management, done when on stage. In this case, the husband did when communicating directly with wives. What appears in front of the stage can be different from what happens behind the stage (Rinawati 2006, 156).

In addition to the examples above, the study of polygamy has been going on for a long time, and this is still a trending topic of discussion until now. The debate about polygamy at the beginning of Islam was represented by the leaders of the thought schools and their followers. Whereas in the latter era have been represented by scholars who are members of progressive Muslim thinkers and gender and feminist activists. However, the theme around polygamy is still relevant to study with other perspectives, as in this study. This research focuses on the reception of the hadith or sunnah about polygamy spread in a new media, how they received and actualized it into new media, both social media and others. These became key messages in this study. This study can be categorized as a public reception study of the 
hadith with an anthropological approach, or it can also be categorized into studies of community behavior in new media.

The data examined is limited to the online media area. It includes several types of media such as webpages, and several social media, especially Facebook and YouTube. The media has been confirmed on a netnographic affiliated to the Indonesian Global Ikhwan. The data of this study were collected in the period between June 2018 to February 2019.

\section{Overview of the Global Ikhwan}

Global Ikhwan is one of the leading community organizations in Malaysia. Several sources state that the Global Ikhwan is a metamorphosis of the Sufistic community named Darul Arqam. Darul Arqam was founded by Azhaari Mohammad in 1960. One of the religious practice that marked this group was the reading of the awrad muhammadiyah.

This awrad has been practiced as a form of wasîlah or tawâsul (intermediary) that relates to the teacher of this group named Shaykh Suhaimi. Shaykh Suhaimi is a person who has supernatural greatness, and he is believed not to die. He is also believed to be Imam Mahdi who has been moksa, and one day will come back on earth (Pribadi 2017, 28). By reading the awrad muhammadiyah, they are sure to be facilitated to arrive at the goals that the readers want.

Darul Arqam itself is essentially not only a group that is synonymous with the tarekat of Sufi, but this is a corporation that has branches in various countries and has a fairly prominent entrepreneurial ethos. This organization not only in Malaysia, but also exist in Singapore, Brunei, and Indonesia.

On August 5, 1994, Darul Arqam was declared as misguided by the Jabatan Kemajuan Islam Malaysia (JAKIM) of the Kingdom of Malaysia because this was assumed to deviate from Islamic teachings and tarnished the Islam chastity. Some accusations assumed are because the group practiced the awrad muhammadiyah and carried out tawâsul to one of the founding teachers of Darul Arqam who had karâmah and cult to him (Bakar and Noor 2015, 122).

After being declared misguided, followers of Darul Arqam formed a new forum called Syarikat Rufaqa' Corporation (SRC) or Rufaqa'. This union was registered to the Malaysian Government in 1997 (Hamid 2009, 11). As a continuation of Darul Arqam's vision and mission, this group is 
not much different from before. This group also considers Azhaari Muhammad as Abuya, Putera Bani Tamim, Rûh al-Muqaddasah and Sâhib alZamân. These three are spiritual titles that have the highest authority in the group. Although this group also moves as a commercial corporation that has spread in various countries, especially ASEAN, it seems that it is still suspected by the Malaysian government. The followers are considered to revive the deviant and misguided teachings of Darul Arqam. They are often hunted and pursued by the government and then arrested. Finally on September 12, 2006, during the reign of Mahathir Muhammad, the SRC was also declared as misguided because it was considered the same as Darul Arqam by JAKIM and then dissolved (Bakar and Noor 2015, 122).

After the SRC had been declared dissolved since 2008, the SRC has been renamed the Global Ikhwan. The Global Ikhwan has continued the existing SRC or Darul Arqam business network. Therefore, it is often found that the mention of the Global Ikhwan, Rufaqa', or Darul Arqam alternately. These three come from the same embryo. Darul Arqam's strength as an economic corporation that is spiritually based; this cannot be underestimated. Azhaari Muhammad, as the founder of Darul Arqam has a strong base at the grassroots, including the political base of Islam in Malaysia (Hamid 2009, 10).

The action of Darul Arqam, which were initially more active in the economic sphere, in his development was also directly involved in practical politics, through a series of criticisms of the government. This community existence is not denied will threaten the democratic nationalist Malaysian government. Darul Arqam, as a Sufi community had followers that want to the Islamic government. If this is true, it could be that the dissolution of Darul Arqam is not solely due to the misguided factor, but the concern of the Malaysian government at that time about the security and conducive state.

In addition to some teachings they brought, it was the call for the polygamous marriage movement with the establishment of Klub Ikhwan Poligami (the Polygamy Ikhwan Club). This club invites men to marry more than one woman and encourages women to volunteer themselves as honey for men who can make it their second, third, or fourth wife.

The group existence is indirectly inspired by other groups that had almost the same vision and goals. For example, in Indonesia, many groups or communities have emerged that speak out about polygamy. Despite 
changes in the model of propaganda and the spread of teachings, it is undeniable that the polygamy idea continues to experience sustainability.

In Indonesia, FKPS (Forum Keluarga Poligami Samara/Samara Polygamy Family Forum) has been established. This forum becomes a forum for collaboration and activities for polygamous families. The forum also helped to provide advocacy for practitioners of polygamy who received uncomfortable treatment by the community. Besides, FKPS is also heard doing the activities of Dauroh Poligami Indonesia. The organizers of this activity were polygamy practitioners from various regions. Through various memes and leaflets, they spread ideas and promote their activities through social media. From the cycle, the Indonesian Polygamy Forum was formed which on several occasions held training tours in various major cities on Java. On a larger scale, the Global Ikhwan Polygamy Club was established in Bandung.

The Global Ikhwan Polygamy Club has also expanded to outside Java, one of which is in Riau. The head office of the Global Ikhwan Polygamy Club is in the Pekanbaru and surrounding areas in the Tanah Putih area, Siak Hulu District, Kampar Regency. The total membership is not less than 30 heads of families (Syafrinaldi and Naimullah 2015, 130).

The more horrendous, women group have established a community named Klub Istri Takut Suami (KITS). This club was declared by Gina Puspita, one of the wives of Dr. Abdurahman Riesdam Efendi, an academic who has four wives. Klub Istri Taat Suami is a branch of the Obedient Wives Club (OWC) first established in Malaysia on June 4, 2011. The club was founded by elite women who were highly intellectual. This group was formed by the Global Ikhwan of Women division. The vision of the club is to eliminate domestic violence and reduce divorce rates (Han 2013, 2).

\section{Virtual Ethnographic Method (Netnography)}

For capturing an Indonesian Global Ikhwan's reception and expression toward the sunnah of polygamy in online media, the authors use a virtual ethnographic or netnographic approach. Netnography is the development of ethnographic approaches commonly used in cultural research. This approach is interpreted as a more progressive and actual approach to capture various phenomena not only in the real world but also in the digital world or the internet.

Ethnography is interpreted as a description process of the cultural reality created by humans from any period. Or it can also be interpreted as a 
way to see cultural reality, both conventional (real) ethnography and virtual (virtual), both of them gave birth to cultural artifacts. However, virtual ethnography is different from conventional ethnography. The complexity of cultural artifacts in netnography is higher than ordinary ethnography (Nasrullah 2016, 139).

This approach urgently stems from the fact that the existence of the internet has been giving birth to artifacts produced by humans that are far more complex than the artifacts that exist in the real world. The emergence of verbal and non-verbal communication, various diction and acronyms of language, and patterns of communication between net citizens are a small part of the products produced by the sophistication of technology and this phenomenon. Murthy argues that the balanced combination of the real world and digital world through netnography analysis is important because it gives researchers a larger and more exciting array (Murthy 2008, 837). Therefore, it is not enough to see the reception and expression of polygamy club members in the online world if only using a conventional ethnographic approach.

Therefore, the faith expressions through online media must be treated specifically with the consideration that what appears on the media surface is not always the same as the actual reality. People can create or form new identities. Even a person's identity is not easily recognized.

In this study, based on netnographic, the researchers conducted a careful search of several online media that has been used by the Indonesian Global Ikhwan to disseminate and promote their ideas and ideas. Some media that become the object of this study are web-page (www.daurohpoligamiindonesia.com; www.forumpoligamiindonesia.com), the official account of the group on Facebook, Instagram, and Youtube channel. The researchers have stated that by a series of ethnographic studies, these accounts are valid, owned, and used by the Global Ikhwan.

\section{Reception Theory of the Quran and Hadith}

The reception theory using to see public acceptance toward the Quran and hadith is quite new compared to the acceptance of audiences toward the media or the acceptance of readers toward literary works. This theory was developed by the Quran and hadith reviewers with several backgrounds. Some reviewer assumed that the Quran and hadith are texts as well as the greatest literary works. Although in this case, the position of the Quran is more dominant than the hadith. Understanding and culturing 
both of them as dynamic scriptures is also an important factor in the development of this theory. In addition, the study of hadith in more specifical has experienced stagnation in the area of study of texts and sanad. These are contributing to the birth of this study. The reception toward the Quran and hadith is a methodological development which can then be included or categorized into the study of living Quran and/or hadith (Ahimsa-Putra 2012), or Everyday Quran and/or hadith (Saputro 2015). The existence of this study is also to see sunnah or hadith proportionally. Hadith that have existed thousands of years ago were poured out in this era in the form of "living sunnah." (Nasrulloh 2014, 24).

Generally, reception theories will be easy to find in literary research and media research. Reception in literary research can be interpreted as the response or action of the reader toward a literary work. Whereas in media research, acceptance is made by the audience when responding to media products both visually and non-visually.

Thus, the reception itself by several scholars is used to see the response, expression, or acceptance made by the community towards the Quran and hadith. With the argument, that the way of the religion of the Muslim community is inseparable from the norms contained in the Quran and hadith directly. These cannot also be avoided from diverse acceptance. Then the receptive approach becomes an interesting approach to see this phenomenon.

Sam D. Gill, as quoted by Van Voorst and Muhammad Ali, stated that the holy book could be seen from its informative and performative functions. The informative aspects of the Quran are interpreted as forms of public response that make the scriptures a source of knowledge, doctrine, history, scientific cues, and so on. Whereas the performative aspect, the holy book is experienced, utilized as a sacred object, hold strongly and sacred, made a source of the state or society law, used as a tool to bless, be heard and contested, and so on (Gill 1985; Voorst 2016; Ali 2015, 147-67).

Based on this perspective, according to Ghozali, Lutfi, and Abdalla, the informative element of a holy book is reflected in its function as "text" and someone gets information about something. The performative aspects of the scriptures are reflected in their function as "objects" used in a social moment ritual. The second function is more identical as part of social action (Ghozali, Luthfi, and Abdalla 2009, 67).

In addition to an explanation of this theory position and its relevance in the study of hadith, it is also important to distinguish between 
reception, tafsîr, and hermeneutics. According to Zuhri and Dewi, if the tafsîr is more directed at an interpretation, while hermeneutics emphasizes more on a set of rules or principles in interpreting texts, including scriptures (Zuhri and Dewi 2018, 69).

\section{Expression toward the Reception of Polygamy Sunnah}

The Polygamy Club of Indonesian Muslim Global Ikhwan accepts the sunnah of polygamy as contained in several memes disseminated through social networks, both through web pages, Facebook, YouTube, and Instagram. The acceptance of the hadith carried out implies to carry out acts of polygamy with various efforts.

In the domain of the Quran and hadith studies, acceptance can be categorized as a reception. The reception of the Quran and hadith can include three types, namely exegesis reception, aesthetic reception, and functional reception. Ahmad Rafiq as quoted by Zuhri and Dewi, distinguishing the three. Exegesis reception in the form of interpretive and meaningful action, aesthetic reception is more on the treatment of the text (the Quran or hadith) through the beauty that is sung and praised to Quran, while the functional reception is by treating the text (scripture) with practical and benefits purposes that the reader will get (Zuhri and Dewi 2018, 69; Rafiq 2014). In this study, the authors see that exegesis receptions and functional receptions are more dominant carried out by the Indonesian Global Ikhwan than the aesthetic reception.

The hadith that is often responded by the Indonesian Global Ikhwan is a hadith about the advice of marriage for those who have been able to because the act is the Sunna of the Prophet. The hadith intended is as follows: "al-nikâh sunnatî fa man raghiba 'an sunnatî fa laysa minnî" (Married is my sunnah, whoever is reluctant to carry out my sunnah is not of my group) (Ibn Mulaqqin 2004, 10478). Although this hadith has a very common 'ibarah, they make this hadith a normative basis and are considered to underlie actions to call for polygamy to men.

They interpret the hadith by exegesis with the order to marry more than one. In one of their expressions published through the media, their memes voiced their voices for polygamy, "While still young, let's do polygamous." Such a reception model seems to have deviated from the actual purpose of the proper marriage order. As if the prophetic hadith legitimizes the desire of the members of the group to legalize marrying more than one easily. 
In addition, the hadith about marriage to reproduce offspring is also a hadith which often perceived as a polygamous order. This is the hadith

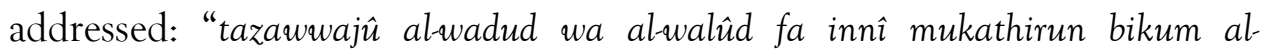
anbiyâ' yawm al-qiyâmah" (Get marry with the beloved woman (ie who loves her husband) and who can have many children, surely I will be proud of your many before the prophets on the day of Judgment) (al-Saqqâf 2015). This kind of hadith text can be found on Musnad works of Ahmad ibn Hanbal hadith number 13594; al-Mu'jam al-Awsat works of al-Tabrânî hadith number 5099, and Sahîh works of Ibn Hibbân hadith number 4028 with the similar text. As in Jâmi' al-Sahîh written by Imam Bukhari, the word al-anbiyâ' is replaced with the word alumam and also by removing the word yawm alqiyâmah at the end of the text. Here is the text: "tazawwajû al-wadud wa alwalûd fa innî mukathirun bikum al-umam" (Get marry with the beloved woman (i.e. who loves her husband) and who can have many children, surely I will be proud of your many before the people (the former) (al-Saqqâf 2015). By polygamy, the goal to reproduce offspring will be more easily achieved. By having more than one wife, every male has the potential to have a lot of wealth.

The more interesting to study is the hadith that widely perceived are the hadith about the prohibition of the wife's refusal when the husband invites her to have sexual relations. "Idhâ da'â al-rajul imratahu ilâ firâshihî fa abat an tajı̂'a, la'anathâ al-malaikat hattâ tuşbiha" (If a husband invites his wife on his bed, but he does not obey it, the Angels will curse him until morning) (alBukhârî 2002, 5193). These have been responded more by many scholars and social workers. This reception type is easily found in the explanations (sharh) of hadith by classical Muslim scholars. The difference between the two is, if the classical Muslim scholars interpreted this order as part of a wife's obedience to her husband and did not associate it with matters of polygamy, the Indonesian Global Ikhwan relates this with the call for polygamy.

Furthermore, the exegesis reception can also be found functionally in their actions. The functional reception here is interpreted as an approach to see that a hadith functions informatively and performatively. The idea of information and performance as two forms of function in understanding the text (in this case, the hadith of the prophet) has been stated by Sam. D. Gill (Gill 1985). Informatively, the prophetic hadith is a source of information for an act of Muslims. In other words, that informative function is understood as an interpretive approach to ascertain what is 
written in a text. Thus, the practice of polygamy carried out by the Indonesian Muslim Ikhwan was essentially inspired by the hadith of the Prophet. In addition, they have also been inspired by the sirah (history) of the prophet who in his life history had more than one wife.

In addition, their acceptance toward the sunnah of polygamy is more directed at realist interpretation and tafsîr. Realist interpretation is interpreted as a form of tafsir that emphasizes the reality of today's social life. In the language of Zainul Munim, realist-tafsîr is a real interpretation in real life (Mun'im 2017, 204). In this context, the Global Ikhwan has a point of view that when male and female relations are increasingly uncontrolled, then the act of polygamy is the right interpretation and very realist in order to marry.

In addition, their acceptance toward the Sunnah of polygamy has also shifted from most interpretations to it. In one of the articles uploaded on the personal page of one of the Global Ikhwan activists, according to them, polygamy is a form of the implementation of the sunnah matrûkah or sunnah mahjûrah (Fadjri 2017). According to researchers, this is a unique form of reception. They interpret the sunnah matrûkah as the Sunnah of the prophet, which is not much done and followed by Muslims. Accordingly, the article mentioned male as followers of polygamy are minority men. There aren't many who can and dare to take polygamy. This reception illustrates that polygamy is one of the ideal male characteristics who follows the prophetic sunnah because not everyone can do it.

According to this group, a male who is not polygamous is mentally weak men. The man did not fully hold on to the commandments of religion, that men were destined to have more than one wife. For the wives, according to the Indonesian Global Ikhwan, they should not act dominantly in the family. Or in other words, women do not forbid their husbands from doing polygamy. Furthermore, polygamy does not conflict with human nature, but it is contrary to the lust of the woman herself. Women who reject polygamy are women who feel that they have their husband and do not provide opportunities to share with other women. Women who did not allow their husbands to remarry had been influenced by their desires. Of course, this is contrary to the purpose of marriage, namely to uphold the religion of God fully and carry out God's commands (Linda n.d.). Based on this statement seems to be an acceptance that places the position of women with a lower degree than men. 
Pro-polygamous voices based on the acceptance of the Prophet's hadith were also campaigned by the akhwat and wives of the polygamous family. The communities formed such as the Obedient Wives Club (OWC) or Klub Istri Takut Suami (KITS) is very active in encouraging women to be ready to be married by men based on polygamy. They captured the hadith message about the recommendation of marriage for more than one woman as a test of faith for them. The wives of the Polygamy Club of Indonesian Global Ikhwan joining the community consider that polygamy has applied the concept of wife total obedience to her husband.

In more privacy areas, a wife is instructed to serve her husband to have total sexual relations. Even at a certain level, treating wives as sex workers are far nobler than men having to fall into prostitution and adultery (Kuhn 2012). In Malaysia, this group also had criticism from various people, with its publication entitled, Seks Islam, Perangi Yahudi untuk Kembalikan Seks Islam kepada Dunia (Sex Islam, Fighting Jews to Return Islamic Sex to the World)." This book illustrates that sex with a wife, even more than one, should be campaigned rather than indulging in pornography or the like (Golingai 2011).

Liz Gooch, one of the Post Magazine reporters, interviewed several Klub Istri Taat Suami activists. From several respondents' statements indicate that their interpretation toward the sunnah polygamy is based on several controversial interpretations. For example, the statement of Rohaya Mohamad as vice-president of the Klub Istri Taat Suami:

"If a man is not satisfied in his sexual needs or his mind or spiritually, he becomes violent. A hungry man is an angry man. Such men are compelled to turn to prostitutes. 'They come home and see a wife who smells bad or doesn't dress up well, doesn't perform sex well and then nagging, things like that, it doesn't help, so he strays" (Gooch 2015).

In the interview, the wives who agreed to be polygamy has a point of view that a good wife is someone who obeys her husband, fulfills husband's sexual needs and takes care of homework. She also added that in Malaysia, such women were not easy to find.

Other evidence which states that fulfilling sexual needs for husbands is a priority, as interpreted by Fauziah Ariffin, when denying the accusations from the contra group, that the activities of sexual servants maximally are like prostitution: 
"When we said that husbands should treat their wives like first-class prostitutes, we were not putting wives on the same level with prostitutes. We are talking about first-class elite types, not street hooker types. Ordinary prostitutes can only provide good sex, but not love and affection, which only a wife can provide."If we provide our husbands [with] more than a prostitute can give, then he will not go out looking for it" (Hodal 2011).

Mrs. Maznah, as an activist at the Klub Istri Taat Suami in Malaysia, also stated similar arguments about the orientation to establish the club:

"The club believes a crucial part of that joy, and obedience is found in the bedroom. Domestic abuse happens because wives don't obey their husband's orders. A man must be responsible for his wife's well-being, but she must listen to her husband. Wives in the club are taught that providing husbands with a fulfilling sex life would prevent them from going to prostitutes. To entertain their husbands is compulsory. If she doesn't do this, the husband will look for another woman. And the house will break down. Wives should welcome them with sexy clothes and alluring smiles when in the privacy of their own homes. Some wives want to get married for leisure, but they don't know the responsibility" (MacKinnon 2011).

Based on these statements illustrated that their totality to serve their husbands, including in bed is an effort to get closer to God. In addition, there are many benefits for women who are married by men with polygamy. Polygamy also makes someone will get God's love (Nisa' 2009, 4). Polygamy is also a very good effort to help and protect women's rights.

Based on the view of Gina Puspita, there are many benefits and goodness to be gained by sharing a husband. For her, polygamy does not make women always dependent on men. Although initially jealous of the other wives when perceived lively and interpreted as the great purpose of polygamy, polygamy itself is the toughest examination that will test the faith of a woman (Arasy 2011).

From these statements makes clear that women are subordinated and their authority is limited. From various brochures or their publication, for example, "Cara Kilat dapat 4 Istri" (Quick way to get four wives) in figure 1 and "Cara Kilat Dapat Istri Empat" (Quick way to get four wives) in figure 2 have placed the wife's position as merchandise. 
Figure 1

A quick way to get 4 wifes

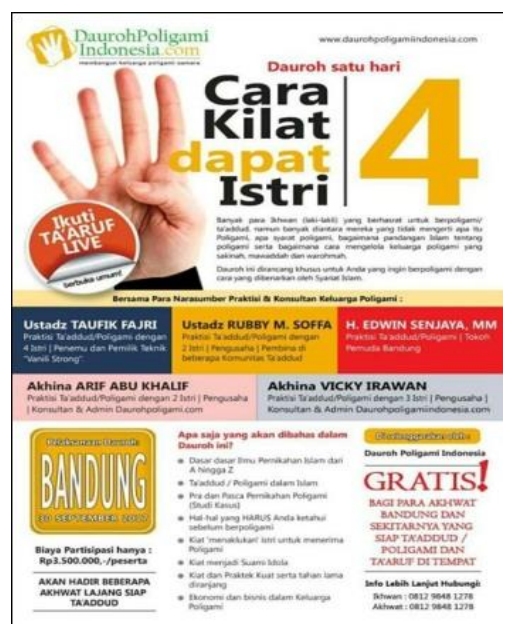

Figure 2

Quick way to get four wifes

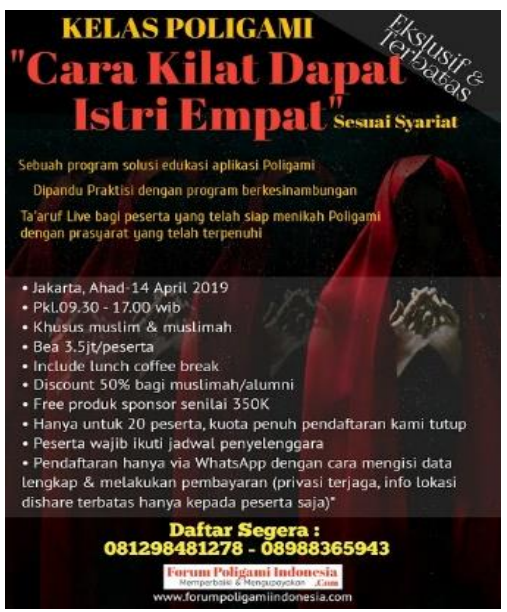

\section{Polygamy as a Cultural Expression for Urban Muslims}

Religion and culture are two subjects that inseparable and interrelated. Religion, as a cultural system, as theorized by Clifford Geertz, plays a role in giving birth the ethos and way of life for its adherents. This ethos and way of life are derived from the profound meanings of religious symbols believed by the community (Pals 2012, 344). Therefore, revelation or in a becoming formula (read: the holy book) naturally forms a psychological framework in the minds of humans that constructs his way of life. Or in other words, that culture driven by religious inspiration is a result of the dialectical process of humans with revelations which they believe (Geertz 1976).

Based on the theory above, polygamy originating from Islamic norms is indirectly articulated by the Global Ikhwan community with its model and method. In some of the statements of a proponent of this idea, polygamy activities are a form of a counter to western culture, which is considered to break Islamic norms. This idea is called a way of life. They take many inspirations from the prophetic hadith and believe it as a role model. The Global Ikhwan's distinctive style in accepting the sunnah of polygamy is also closely related to the current flow of modernity. They use social media as a tool to express a variety of ways. 
In other words, what has been perceived by the Global Ikhwan and expressed through social media as a channeling form between the strength of the text inherent in the community and modernity that continues to experience change and development? They understand that efforts to carry out ideas about the Sunnah of the prophet have been modified in such a way that is in line with the times, although they are more conservative in reality. It cannot be denied because, in its history, the acceptance of Indonesian Muslims towards Islam runs in tandem with the local tradition and regional culture, through understanding the religion and also the biases of modernity (Zuhri and Dewi 2018, 70).

Religion with modernity biases in this study seems more prominent. The ideas of the Indonesian Global Ikhwan Polygamy Club are poured through website media and social networking media such as YouTube, Facebook, WhatsApp, and Instagram.

Among their most visible expressions in the universe of new media (the internet) is the implementation of polygamy, which is disseminated (viral) through online media. From the website www.daurohpoligamiindonesia.com, anyone can see the various information about the activity. This cycle is a kind of short course that presented by presenters who does polygamy with two, three, or four wives. This dauroh also invites akhwat(s) who are ready to be the second wife.

For women who are willing to become polygamous wives (second wives), they will accept intensive guidance. The guidance is intended to prepare mentally, psychologically, as well as religious understanding about polygamy. So, they can become a loyal wife totally to her husband. In the event, ta'ârruf's guidance was also held directly. Both men and women who are ready for polygamy presented in a place and mediated by one of the group's supervisors.

These activities are unique, who are interested in polygamy should pay quite a lot of money compared to women. As for the interested girls without having to pay a penny. This phenomenon is certainly awkward and questionable. Probably, this is what authors said earlier that in this disruption era, religion became a commodity traded. Then, is there a business motivation in cycling activity? Of course, these need to be a separate study in detail.

In addition, cycle activities are held in luxurious places. It could be that they want to show that polygamy is a normal thing, not a taboo doing 
for Muslims. Unfortunately, this activity looks exclusive and closed. Not everyone can get information unless they have been registered as a member.

This polygamy club is also very active in creating videos and audio of da'wah, modules, and various articles about the promotion of polygamy. For example, Vicky Abu Syamil, a practitioner of polygamy in the community, has a YouTube channel that publishes various daily activities of polygamous families or lectures and motivations about polygamy (Syamil 2018). These digital products are then shared through the social networks they have. Through these facilities, they campaign for anti-freedoms and free association. Practitioners of polygamy who are members of the trainers at the cycle of polygamyindonesia.com also publish various memes that contain calls for polygamy and show the primacy of carrying out polygamy. Among the examples of the meme are as mentioned in figure 3 and 4.

Figure 3

calls for polygamy

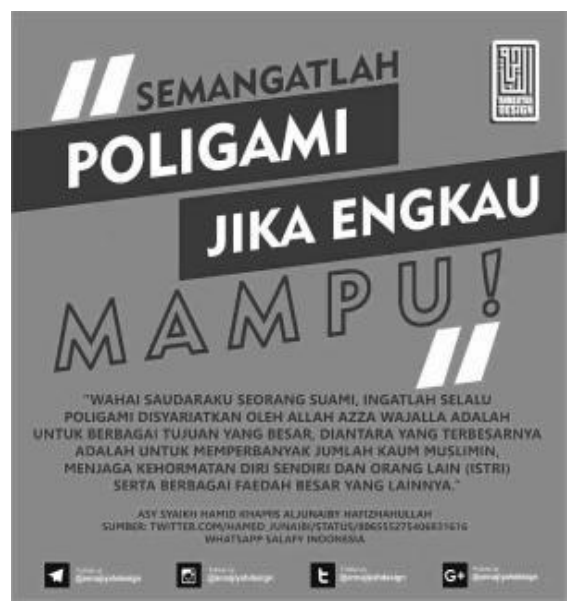

Figure 4

choosing a husband is not easy

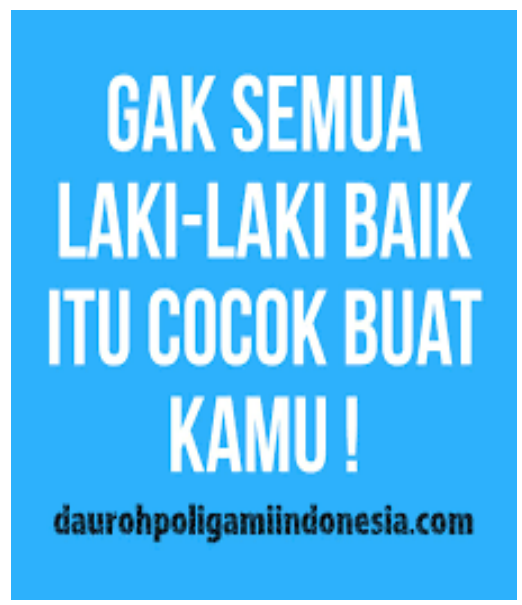

The first meme (figure 3) is a call for polygamy. Polygamy is important because it will get many benefits, such as increasing the number of Muslims and maintaining the honor of husband and wife. The second meme (figure 4) has a meaning that choosing men for women to become partners is not easy. Even those who are impressed good people don't necessarily match. The relationship of the sentence included with the activity of polygamy is that men who are ready for polygamy can be said to be male choices that have been tested as a leader in the family so that it is 
suitable to be made as a companion. Or also interpreted, that not all female soul mates are single men, but it could be someone's husband, and women must be ready to accept that reality.

What they express in the virtual world about polygamy is a tactical step. Through the online world, both producers and consumers of information can communicate verbally and non-verbally. It is what authors call the Global Ikhwan's sensitivity in social communication to deliver their aspirations and message.

Especially in the industrial revolution era 4.0 that moves so dynamically and change is not easy to predict rightly. Religious teachings for them must be responded with literacy to change and capture opportunities for da'wah. Probably, because religion acts as another who does not always interact directly with the virtual world, the effort to integrate and approach it or incorporate it into a single entity is an effort to conduct.

Although the digital era existence reduces and even shifts authority and religious values, people trust more about things neutralized through social media than meeting authoritative religious experts. On the other hand, this phenomenon of the uncertainty of indirect sources of religious reference will also give birth to legal flexibility about something.

It means that there is an opportunity for anyone to deliver da'wah messages. Polygamy groups are more flexible to carry out promotions and create social networks. Polygamy practitioners seem of being worthy to be imitated. Important aspects, such as ease of networking, producing authority, unlimited access, were captured by the Indonesian Global Ikhwan as an opportunity. Opportunities are used to distribute the seeds of ideas. The characteristics of new media that do not require users to meet face to face has made prospective practitioners of polygamy are free to learn.

The promotion and publication of polygamy had existed long before this incident, but it was not as semifunctional as on this era. If in the classical era through the media of books that are sold freely as written by Eko Suryono about, Kiat Sukses Beristri Banyak: Pengalaman Puspo Wardoyo Bersama 4 Istri (Successful Ways to Get Many Wives: Experience of Puspo Wardoyo with 4 Wives) (Suryono 2003), but now it is more practical, efficient and can reach a wider society.

As a result, it seems that after the dissolution of Darul Arqam and two changes in name by the Malaysian government, the era of technological disruption became a momentum for the revival of Darul Arqam's vision and mission with a new pattern. The polygamy club of Global Ikhwan 
seems to grow back and get more and more responses from the public, including the Indonesian Muslim community.

\section{Conclusion}

Study about religion cannot be separated from the relationship between tradition or culture, religious doctrine, and modernity biases. All three move around, giving, and receiving colors. In the discourse of contemporary hadith studies, this process can be referred to as a form of channeling, which involves the process of reception, transmission, and expression of society. The reception and expression process more specifically focuses on the sacred text of the religion, in this case, the hadith. It cannot be denied because every believer, especially the revelation religion, including Islam, holds the scriptures tightly as a way of life. It is like the manual book that transformed into a way of life for the reader. Although in practice, what is perceived by Muslims is not always the same as the content in the holy text.

In the context of the discussion about the Indonesian Global Ikhwan community in this article, the group's reception process for the sunnah polygamy became an important model for seeing the types and patterns of reception and expressions they made. The Global Ikhwan conducts exegesis receptions on the sunnah polygamy. The hadiths about the order to get married were received by them and responded with a typical interpretation. For those with polygamy, it is categorized as a follower of the sunnah matrûkah - namely the commands and recommendations of the Prophet that were not followed by Muslims. Even for them, anyone capable of polygamy is a real man, he is a winner, and vice versa is a weak man.

Based on the aspect of functional reception of religious texts as initiated by Sam D. Gill, the recommended hadiths of marriage and sirah of prophets about the life of polygamy function informally rather than performatively. It means that these traditions for the Polygamy Club of Global Ikhwan were a source of inspiration for polygamy.

The follow-up of the receptions they performed has been manifested in various expressions which, in our opinion, also crossed with modernity bias. For example, the practice of Dauroh Poligami Indonesia offered to anyone or lived ta'âruf model, and various pre-polygamy counseling and guidance services are an attempt to express the command of polygamy with informative, open and innovative methods. It can all be categorized into 
urban Muslim religious expressions amid the disruption era, which demands conformity with developments and changes in the times.

The industrial revolution era 4.0, or we call it a technological disruption era for them is also a valuable momentum to disseminate their ideas, this is the result of the reception of the prophetic hadith about polygamy. The ease of technology, especially social networks that are wireless and can be reached by anyone is used in promoting the importance of practicing polygamous marriage. Not infrequently, their activities reap the pros and cons. Nonetheless, so far until this article was written, their enthusiasm for voicing the practice of sunnah matrûkah continued even more and more glimpsed and attracted by many people from various walks of life.

\section{References}

Ahimsa-Putra, Heddy Shri. 2012. "The Living Al-Qur'an: Beberapa Perspektif Antropologi." Walisongo: Jurnal Penelitian Sosial Keagamaan 20(1): 235-60.

DOI: http://dx.doi.org/10.21580/ws.20.1.198

Ali, Muhammad. 2015. "Kajian Naskah dan Kajian Living Qur'an dan Living Hadiith." Journal of Qur'an and Hadiith Studies 4(2): 147-67. DOI: https://doi.org/10.1548/quhas.v4i2.2391

Arasy, Rasul. 2011. "Klub Istri Taat Suami: 'Kami Adalah Pejuang Poligami."” https://www.arrahmah.com/2011/06/26/klub-istri-taatsuami-kami-adalah-pejuang-poligami/ (October 24, 2018)

Bakar, Nurul Ayu, and Ahmad Yunus Mohd Noor. 2015. "Tahap Kefahaman dan Persepsi Masyarakat Terhadap Global Ikhwan Sdn. Bhd.” In Prosiding Kolokium Antarabangsa Siswazah Pengajian Islam (KASPI). Selangor: Fakulti Pengajian Islam, Universiti Kebangsaan Malaysia, 122-31.

al-Bukhârî, Muhammad ibn Ismâ'îl. 2002. al-Jâmi' al-Sahị̂h. Beirut: Dâr Ibn Kathîr.

Darmawijaya, Edi. 2015. "Poligami Dalam Hukum Islam dan Hukum Positif (Tinjauan Hukum Keluarga Turki, Tunisia, dan Indonesia).” Gender Equality: International Journal of Child and Gender Studies 1(1): $27-38$. 
DOI: http://dx.doi.org/10.22646/jcgs.v1i1.621

Elkarimah, Mia Fitriah. 2018. "Pendekatan Linguistik Syahrur Pada Ayat Poligami.” MAGHZA: Jurnal Ilmu Al-Qur'an Dan Tafsir 3(2): 164-74. DOI: https://doi.org/10.24090/maghza.v3i2.2129.

Fadjri, Taufik. 2017. "Lelaki Minoritas." https://daurohpoligamiindonesia.com/lelaki-minoritas/ (October 24, 2018).

Geertz, Clifford. 1976. The Religion of Java. Chicago: University of Chicago Press.

Ghozali, Abd Moqsith, Luthfi Assyaukanie, and Ulil Abshar Abdalla. 2009. Metodologi Studi Al-Qur'an. Jakarta: PT Gramedia Pustaka Utama.

Gill, Sam D. 1985. "Nonliterate Traditions and Holy Book: Toward a New Model." In The Holy Book in Comparative Perspective, ed. Frederick Mathewson Denny and Rodney Leon Taylor. Columbia: University of South Carolina Press.

Golingai, Philip. 2011. "Anti-Climax in 'Seks Islam' Book." https://www.thestar.com.my/opinion/letters/2011/10/31/anticli max-in-seks-islam-book/ (August 24, 2018).

Gooch, Liz. 2015. "The Obedient Wives Club: For Better or for Worse." http://www.scmp.com/magazines/postmagazine/article/1841423/ obedient-wives-club-better-or-worse (August 24, 2018).

Hodal, Kate. 2011. "Outrage as Obedient Wives Club Spreads across South-East "Asia." http://www.theguardian.com/world/2011/jul/06/outrage-atobedient-wives-club-singapore (August 25, 2018).

Ibn Mulaqqin, 'Umar ibn 'Alî. 2004. al-Badr al-Munîr fî Takhrîj al-Ahâdîth wa al-Athar al-Wâqi'ah fî Sharkh al-Kabîr. Saudi Arabia: Dâr al-Hijrah.

Kuhn, Anthony. 2012. “'Obedient Wives Club' Irks Some Muslims in Malaysia."https://www.npr.org/2012/01/30/146066783/obedientwives-club-irks-some-muslims-in-malaysia (August 25, 2018).

Linda H. n.d. "Gina Puspita: 'Poligami Tidak Menentang Fitrah Manusia.” http://www.muslimdaily.net/artikel/opini/gina-puspita-poligamitidak-menentang-fitrah-manusia.html. (July 1, 2018). 
MacKinnon, Ian. 2011. "Malaysia: The Obedient Wife Club... from the Makers of the Polygamy Club," https://www.telegraph.co.uk/news/worldnews/asia/malaysia/8827 091/Malaysia-The-Obedient-Wife-Club...-from-the-makers-of-thePolygamy-Club.html. (July 1, 2018).

Mulia, Siti Musdah. 2004. Islam Menggugat Poligami. Jakarta: Gramedia Pustaka Utama.

Mun'im, A Rafiq Zainul. 2017. “Tafsir Realis Terhadap Makna dan Simbol Alquran Bagi Masyarakat Kabupaten Probolinggo.” MADANIA: Jurnal kajian Keislaman 21(2): 193-208. DOI: https://doi.org/10.29300/madania.v21i2.624.

Murthy, Dhiraj. 2008. "Digital Ethnography: An Examination of the Use of New Technologies for Social Research.” Sociology 42(5): 837-55.

DOI: https://doi.org/10.1177/0038038508094565.

Nasrullah, Ruli. 2016. Teori dan Riset Media Siber (Cybermedia). Jakarta: Kencana.

Nasrulloh, Nasrulloh. 2014. "Rekonstruksi Definisi Sunnah Sebagai Pijakan Kontekstualitas Pemahaman Hadits." ULUL ALBAB Jurnal Studi Islam 15(1): 15-28.

DOI: https://doi.org/10.18860/ua.v14i3.2659.

Nisa', Nurun. 2009. "Klub Poligami Memantik Kontroversi." The Wahid Institute. November 2009.

Pals, Daniel L. 2012. Seven Theories of Religion. Tras. Inyiak Ridwan Muzir and M Syukri. Yogyakarta: IRCiSoD.

Pribadi, Nukhan Wicaksana. 2017. "Forms of Activities and Public Reaction to Religious Splinter Movement of Jamaah Darul Arqam in Malang, East Java." The International Journal of Humanities $\mathcal{E}$ Social Studies 5(5): 28-33.

Rafiq, Ahmad. 2014. "The Reception of the Qur'an in Indonesia: A Case Study of the Place of the Qur'an in a Non-Arabic Speaking Community." Dissertation. Temple University Philadelphia.

Rinawati, Rini. 2006. "Dramaturgi Poligami." Mediator: Jurnal Komunikasi $7(1): 147-62$. 
DOI: https://doi.org/10.29313/mediator.v7i1.1226.

Saputro, M. Endy. 2015. "Everyday Qur'an Di Era Post-Konsumerisme Muslim." Mutawâtir: Jurnal Keilmuan Tafsir Hadis 5(2): 179-200.

DOI: https://doi.org/10.15642/mutawatir.2015.5.2.179-200

al-Saqqâf, "Alawî ibn 'Abd al-Qâdir. 2015. "al-Durar al-Sunniyyah: alMawsu'ah al-Hadithiyyah.” https://www.dorar.net/hadith/sharh/83095 (October 24, 2018).

Suryono, Eko. 2003. Kiat Sukses Beristri Banyak: Pengalaman Puspo Wardoyo Bersama 4 Istri. Solo: Bumi Wacana.

Syafrinaldi, and Naimullah. 2015. "Pola Perkawinan Club Poligami Global Ikhwan Menurut Hukum Islam (Studi Kasus Di Kecamatan Rumbai Kota Pekanbaru." Hukum Islam 15(1): 129-42.

DOI: http://dx.doi.org/10.24014/hi.v15i1.3077

Shahrûr, Muhammad. 1992. al-Kitâb wa al-Qur'ân; Qirâ'ah Mu'âshirah. Damascus: al-Ahâlî.

Syamil, Vicky Abu. 2018. "Cara Kilat Dapat Istri 4.” April 22, 2018. https://www.youtube.com/watch?v=MB0NugU1DEA. (December 20, 2018).

Voorst, Robert E. Van. 2016. Anthology of World Scriptures. Cengage Learning.

Zuhri, Saifuddin, and Subkhani Kusuma Dewi. 2018. Living Hadis; Praktik, Resepsi, Teks, dan Transmisi. Yogyakarta: Q-Media. 